\title{
TECHNOLOGY AS PILLAR FOR ESSENTIAL OIL GREEN EXTRACTION
}

Carlos Alberto Tosta Machadora, Herman Augusto Lepikson', Matheus Antônio Nogueira de Andrade c, Yasmim Thasla Santos Ferreira ${ }^{d}$, Sara Freitas Santos Vasconcelos ${ }^{\mathrm{e}}$

a Senai Cimatec University Center, Orlando Gomes Avenue, 1845 - Piatã, Salvador, BA, 41650-010, Brazil, carlos.tosta@uol.com.br

${ }^{\circ}$ Senai Cimatec University Center, Orlando Gomes Avenue, 1845 - Piatã, Salvador, BA, 41650-010, Brazil, herman.lepikson@fieb.org.br

- Universidade Federal da Bahia, Av. Adhemar de Barros, s/nº - Ondina, Salvador BA, 40170-110, Brazil, matheus.andrade.Ip@gmail.com

a Senai Cimatec University Center, Orlando Gomes Avenue, 1845 - Piatã, Salvador, BA, 41650-010, Brazil, yasmim.thasla@gmail.com

- Senai Cimatec University Center, Orlando Gomes Avenue, 1845 - Piatã, Salvador, BA, 41650-010, Brazil, sarasantoos500@gmail.com

\begin{abstract}
This paper focuses on essential oil (EO) extraction via steam distillation and the technological possibilities to enhance both operational and environmental performances. Being steam distillation the most common extraction method $(93 \%$ of the worldwide produced volume) the inefficiencies in these production systems become a concrete target for improvements. A green extraction approach is brought, side by side with technology upgrade, in order to creating an evolutionary path for this industry, starting from a real process design in its current technology status, property of Linax Indústria e Comércio de Óleos Essenciais, and applying digital technology to enhance process effectiveness both in terms of material and energy balances, with direct effects over environmental performance.
\end{abstract}

Keywords: essential oils; green extraction; digital technology.

Resumo: Este artigo enfoca a extração de óleo essencial (OE) por destilação a vapor e as possibilidades tecnológicas para melhorar o desempenho operacional e ambiental. Sendo a destilação a vapor o método de extração mais comum $(93 \%$ do volume mundial produzido), as ineficiências nesses sistemas de produção tornam-se um alvo concreto para melhorias. Uma abordagem de extração verde é trazida, lado a lado com a atualização tecnológica, a fim de criar um caminho evolutivo para esta indústria, a partir de um processo real, em seu status atual de tecnologia, propriedade da Linax Indústria e Comércio de Óleos Essenciais, e aplicando tecnologia digital para aumentar a eficácia do processo em termos de balanço de materiais e energia, com efeitos diretos sobre o desempenho ambiental.

Palavras-chave: óleos essenciais; extração verde; tecnologia digital 


\section{INTRODUCTION}

The remarkable growth of natural products market is justified by consumers movement from industrialized food to natural products. The plant extracts market was US $\$ 23.7$ billion in 2019, expecting to reach US\$ 59.4 billion by 2025 , according to marketsandmarkets.com [1] Essential oils (EO) market, part of this value, is mentioned by alliedmarketsearch.com [2] as US\$ 8 billion in 2018 reaching approximately US\$ 16-17 billion by 2026 .

Green extraction principles subsidize the pursue for more efficient process with reduced number of unit operations, optimized process time, energy requirements and minimum or zero waste generation. It is important to note that this is an industry with many small producers, which still operates in a very artisanal and empirical way [3, 4].

Figure 1 shows the six green principles [4] applied to inputs and outputs of an extraction process which, when optimized, are responsible for delivering environmental gains and higher efficiencies with ultimate effect on business financial margins.

Figure 1. Green principles applied to extraction processes

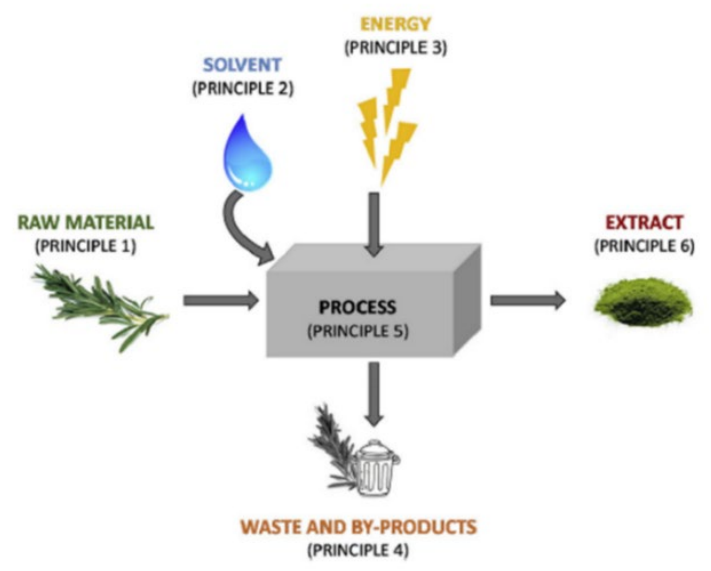

Adapted from Chemat [4]

Digital technology, lately under the label industry 4.0, proposes potential enhancements when properly applied to the green principles [5]. The essential oil extraction industry still needs attention even in the basic engineering aspects, such as energy recovery, efficient thermal insulation and pre-heating capabilities [6]. Nevertheless, the focus of this paper is to point out the business opportunities attached to technology update, serving as a watch out for those in charge of production administration and company owners, with evident impact on environmental performance. In this context, from the plant floor reality to the upper management levels, the control, monitoring and management of the essential oil extraction industry is a concrete subject for this renewal wave, meaning that operational and environment excellence cannot exist without these attributes. In Figure 2 the instrumentation and process control level are represented by three levels: the first operates at the shopfloor and is represented by sensors, programmable logic controller (PLC) and process control level (SCADA - Supervisory, Control and data Acquisition system. The second, (plant management system) the Manufacturing Execution System (MES) connects all productive activities to the Enterprise Resource Planning (ERP), which is the third one. ERP operates the company organizational areas, for management purposes [7]. MES is the enabler system to follow and administrate the manufacturing 'in progress', step by step and in real time: overall manufacturing control, time-to-market, overall 
manufacturing visibility, capacity allocation, among other capabilities. MES evolution, within the 4.0 scenario, is integrated to the so called cyber-physical space (CPS), where multilevel virtual and real worlds are merged [8].

Figure 2. Evolution: from conventional to 4.0 configuration

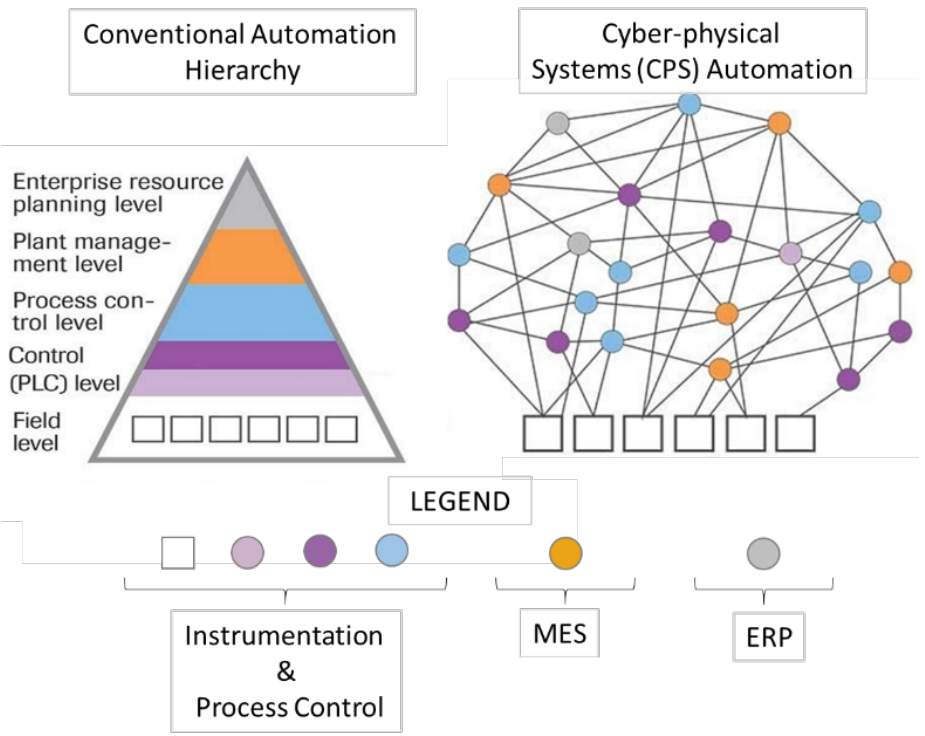

\section{Adapted from www.foodengineeringmag.com}

Table 1 was built to reflect some of the technological possibilities applicable to the six green principles, enlightening but not restricting the objectives of the present paper. The columns are connected from left to right, demonstrating - through the arrows - how the more basic systems subsidize the next.

Table 1. Technological possibilities applied to EO industry

\begin{tabular}{|c|c|c|c|}
\hline & $\begin{array}{l}\text { Instrumentation \& } \\
\text { Process Control }\end{array}$ & $\begin{array}{l}\text { Big Data \& } \\
\text { Analytics }\end{array}$ & $\begin{array}{c}\text { Simulation \& Machine } \\
\text { Learning }\end{array}$ \\
\hline $\begin{array}{l}\text { Raw Material } \\
\text { (Principle 1) }\end{array}$ & $\begin{array}{l}\text { Analytical Values for } \\
\text { humidity, apparent } \\
\text { density, targeting yield } \\
\text { improvement. }\end{array}$ & $\begin{array}{l}\text { Data is intelligently } \\
\text { analyzed to find } \\
\text { correlations and } \\
\text { determining parameters } \\
\text { for self-configuration. }\end{array}$ & $\begin{array}{l}\text { Self-configuration } \\
\text { parameters are optimized by } \\
\text { advanced simulation like } \\
\text { digital twin. The proposed } \\
\text { parameters will reduce batch } \\
\text { time, idling, energy } \\
\text { consumption. }\end{array}$ \\
\hline $\begin{array}{l}\text { Solvent } \\
\text { (Principle 2) }\end{array}$ & $\begin{array}{l}\text { Steam process variables } \\
\text { impact extraction } \\
\text { efficiencies (yield). } \\
\text { Variations cause } \\
\text { undesired effects as the } \\
\text { channeling [10] }\end{array}$ & $\begin{array}{l}\text { The best configuration for } \\
\text { steam parameters will be } \\
\text { determined for next } \\
\text { batches. }\end{array}$ & $\begin{array}{l}\text { Simulation proposes fine } \\
\text { adjustments via machine } \\
\text { learning. These optimized } \\
\text { parameters can be fed into } \\
\text { the control system for next } \\
\text { batches. }\end{array}$ \\
\hline $\begin{array}{l}\text { Energy } \\
\text { (Principle 3) }\end{array}$ & $\begin{array}{l}\text { Sensors and control for } \\
\text { steam and cooling water } \\
\text { loops. }\end{array}$ & $\begin{array}{l}\text { Best configuration for } \\
\text { setpoints and process } \\
\text { times. }\end{array}$ & $\begin{array}{l}\text { Simulation indicates best } \\
\text { values for steam and cooling } \\
\text { water. }\end{array}$ \\
\hline
\end{tabular}




\begin{tabular}{|l|l|l|l|}
\hline $\begin{array}{l}\text { Waste \& by } \\
\text { products }\end{array}$ & $\begin{array}{l}\text { Solid and liquid residues } \\
\text { (Pydrosol) can be } \\
\text { analyzed and } \\
\text { commercialized as } \\
\text { valuable products. }\end{array}$ & $\begin{array}{l}\text { Composition of Essential } \\
\text { oil and hydrosols indicate } \\
\text { process trends for } \\
\text { cooling water and time of } \\
\text { residence parameters. }\end{array}$ & $\begin{array}{l}\text { Composition of hydrosols in } \\
\text { condensed water is } \\
\text { predetermined from raw } \\
\text { materials and process } \\
\text { conditions. }\end{array}$ \\
\hline $\begin{array}{l}\text { Process } \\
\text { (Principle 5) }\end{array}$ & $\begin{array}{l}\text { Sensors for all variables } \\
\text { inside/outside the } \\
\text { extraction vessel are } \\
\text { relevant to detect } \\
\text { undesired conditions. }\end{array}$ & $\begin{array}{l}\text { Process data is valuable } \\
\text { to feed real tome } \\
\text { simulators as well as to } \\
\text { determine correlations. }\end{array}$ & $\begin{array}{l}\text { Real time process simulators } \\
\text { (digital twin) detects } \\
\text { deviations from ideal } \\
\text { process behavior. }\end{array}$ \\
\hline $\begin{array}{l}\text { Product (Extract) } \\
\text { Principle 6 }\end{array}$ & $\begin{array}{l}\text { Instruments to determine } \\
\text { quality analysis of the } \\
\text { finished product and } \\
\text { quantitative indicators } \\
\text { (yield). }\end{array}$ & $\begin{array}{l}\text { Statistic treatment to find } \\
\text { correlations between raw } \\
\text { material, process } \\
\text { conditions and the quality } \\
\text { indicator of the EO. }\end{array}$ & $\begin{array}{l}\text { Process parameters are } \\
\text { continuously improved when } \\
\text { correlations are identified. }\end{array}$ \\
\hline
\end{tabular}

Business peculiarities indicate the direction for investments in new technologies. Financial analysis indicates the best options and their impact in business results: ROI - return on investment; NPV - net present value, among others, encompassing business timeframe. Therefore, the objective in this work is unveiling technology possibilities as a leap toward operational excellence for the essential oils extraction industry, applied to a real process, property of the company Linax.

In fact, the "menu" of possibilities is flexible and complex, requiring a mature organization to support such step forward: people development and training as well as a clear set of objectives become mandatory as basis for the new scenario. Bill Gates reinforces that: "The first rule of any technology used in a business is that automation applied to an efficient operation will magnify the efficiency. The second is that automation applied to an inefficient operation will magnify the inefficiency.", meaning that that the more developed is the organization the larger is the reach of the projects [9].

In this sense, Table 1 highlights the objective of this paper, presenting possibilities and bridging the green principles and technology, as a strategical lever for both academic and industrial developments.

\section{METHODOLOGY}

Methodological trajectory is outlined as described below:]

- Starting point: status of the process in its current conception, within Linax company.

- Steps for technology improvements

- Basic Instrumentation and plant floor level control via PLC.

- Monitoring via SCADA

- MES and ERP

\subsection{Current process design: the starting point for evolution}

Essential oil extraction system, as commonly operated in Linax company, works under usual basic conditions (Figure 3). Then, the extraction operation consists only of applying steam to a green mass through the extraction vessel followed by a postcondensation. This process is performed without sensors and monitoring, meaning that the control tasks are restricted to producers' manual action based on their historic 
experience. This weak technological scenario delivers variable quantities and quality, high energy requirements and equipment idling due to unprepared production sequences and planning. The environmental performance clearly suffers the consequences of this lack of control, representing a large field of opportunities for improvements. The understanding of the process "as is" allows the identification of weaknesses and propositions brought furtherly in this text.

Figure 3. Essential oil extraction original status: without sensors and controls

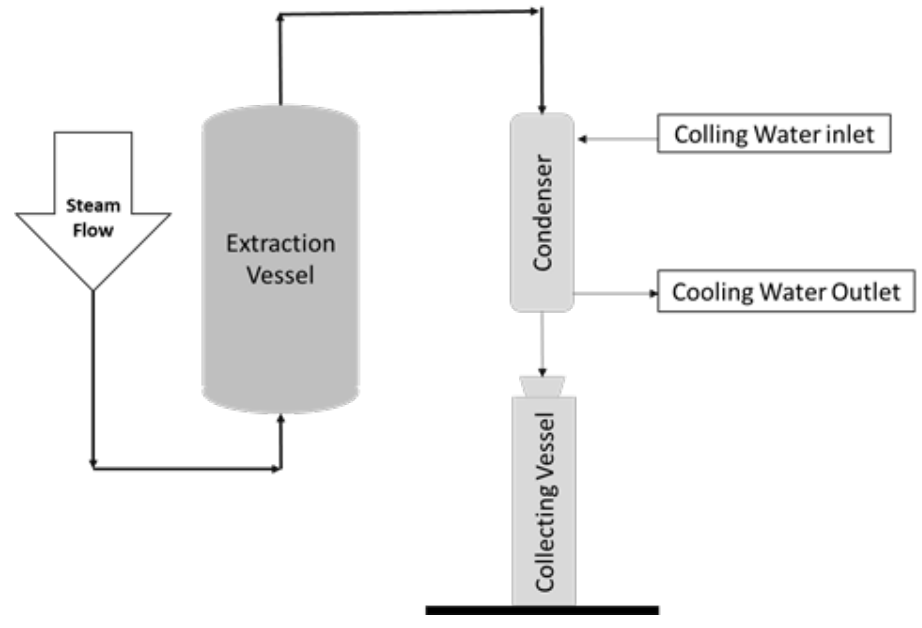

Source: The authors

\subsection{Steps for technology improvements}

2.2.1. Basic Instrumentation and plant floor level control

Figure 4 shows a basic proposition for instrumentation, according to ISA [11] as the first step to improve control when compared to the absolute simplicity of the previous design, mentioned in Figure 3.

Figure 4. Essential oil extraction process with basic instrumentation

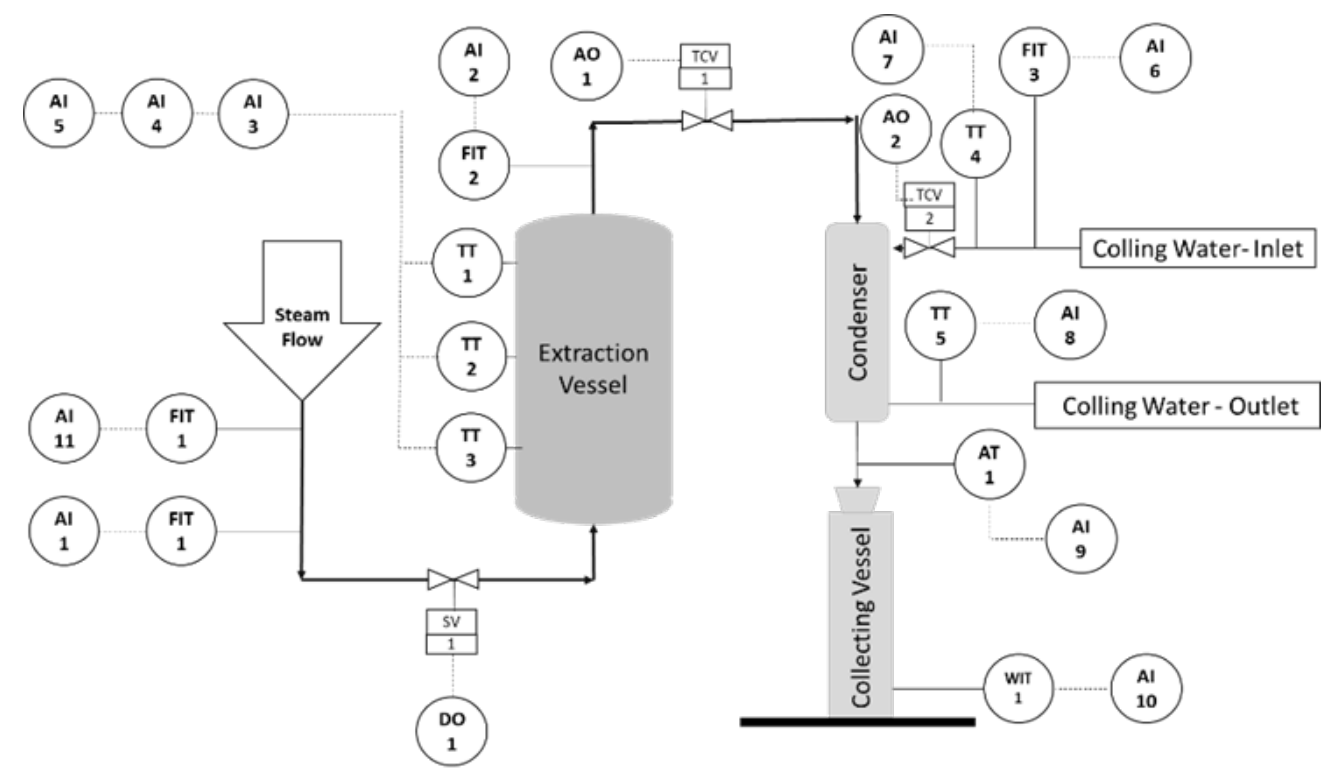

Source: The authors 
Instrumentation and control, even when applied in basic level, allow material and energy balance improvements as well as optimizing process time and repeatability, with direct effect on environmental performance.

\subsubsection{Monitoring: SCADA - Supervisory, Control and data Acquisition system.}

Beyond the plant floor level (field instrumentation shown in Figure 4), there are countless possibilities for controlling, monitoring and managing essential oil extraction process. Figure 5 shows how EO plant floor structure could be connected into a 4.0 proposition [7], using a SCADA system, which can either connect plant floor operation with upper systems or, staying in this level with a richer MMI - Man Machine Interface and friendly access to process parameters, receipts and historic data.

Figure 5. Example control, monitoring and management configuration for EO

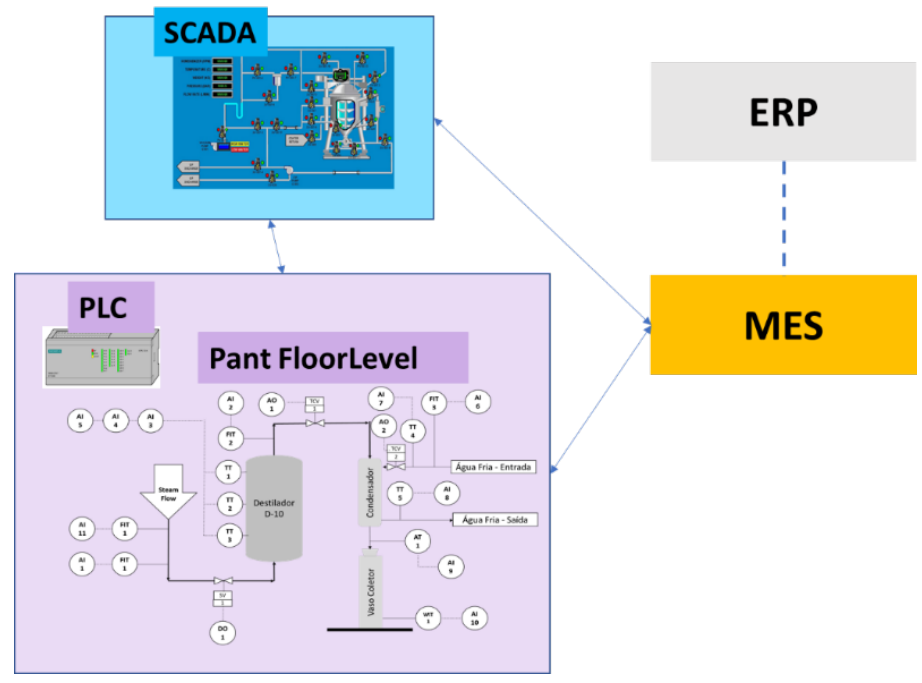

Source: Adapted from mechatrone.com

\subsubsection{MES and ERP}

A complex manufacturing structure requires systems with broader management scope. As example, companies with multi-factory structure, geographically distributed, where in a cooperative mode, as shown in Figure 6, can interconnect facilities to better serve business purposes as well as customer's expectations [8].

Figure 6. Multi-Factory view

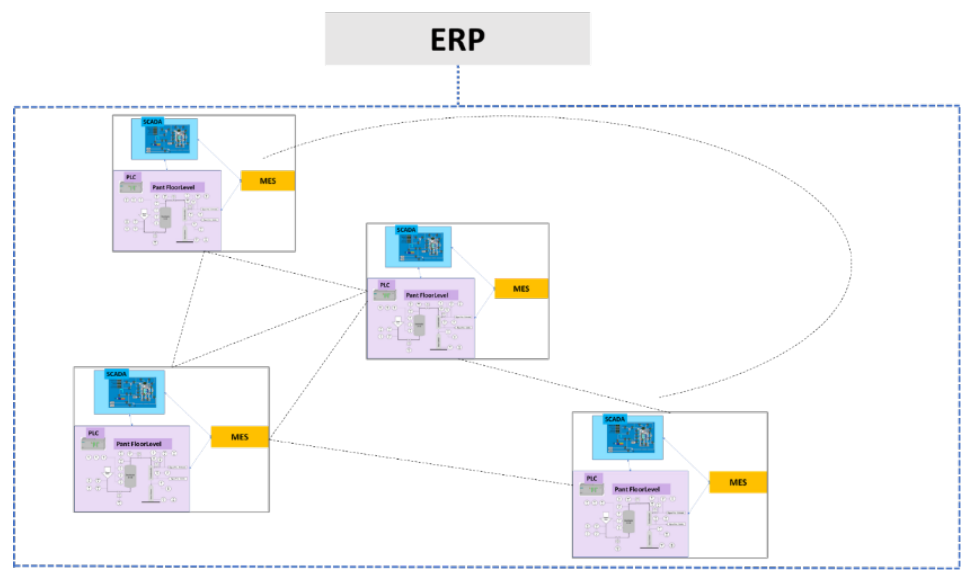

Source: The authors 
The complexity and the set of choices depend on the selection of the right investment, proper planning and excellent installation.

\section{RESULTS AND DISCUSSION}

The technological enhancement possibilities for the EO extraction industry, through steam distillation, can significantly and positively impact extraction time and energy consumption. These improvements have their root in plant instrumentation and control design, followed by data acquisition and analysis, process simulation and machine learning, generating, then, optimized parameters [13]. The possibilities brought in this paper aims at motivating readers to pursue better scenarios in the extraction industry and continuous process improvement within organizations constantly developed to deliver customer, business, people and, importantly, environmental better results [3]. Steam distillation can benefit from these technological advances and, as it uses water as solvent, become one of the most environmentally friendly method of extraction [4].

Beyond profitability, innovation will increase business perpetuity as well as purpose of this paper - environmental performance. Green extraction processes are those qualified to consume less solvent (water) and energy, diminish waste generation and all reduce or eliminate environmental impacts, in parallel to the benefits in business bottom line.

The improvements explored in this paper are just a starting point for a profitable journey. Application of renewable energy, minimization of product quality degradation, better use for subproducts like the condensate (hydrosols) and solid matter remaining from the extraction cycle are side by side with robust control, monitoring and management systems in the relentless quest for environmental care industry performances.

\section{CONCLUSION}

Extraction industry, particularly producers of essential oils, present excellent opportunities for technology updating, aiming at better yields, optimized energy consumption and minimum waste generation. The quest for operational excellence consists of a set of actions and projects, both technological and organizational, that will impact on the business overall: safety, quality, reliability, good manufacturing practices, costs and - as the central idea of this paper - reduction or elimination of environmental impacts, reaching the level of what can be called green extraction. The wave, labeled as industry 4.0 , brings a comprehensive portfolio of propositions, few of them mentioned in this paper, to enable not just a better yield, quality, capacity management and energy efficiency, but a considerable improvement in environmental performance.

\section{Acknowledgments}

Authors are grateful for the financial support from the BAHIA STATE RESEARCH FOUNDATION - FAPESB for the research grant awarded (5633/2019). 


\section{REFERENCES}

${ }^{1}$ www.marketsandmarkets.com/Market-Reports/plant-extracts-market-942.html

2 www.alliedmarketresearch.com/essential-oils-market

${ }^{3}$ CHEMAT, Farid; VIAN, Maryline Abert; CRAVOTTO, Giancarlo. Green extraction of natural products: concept and principles. International journal of molecular sciences, v. 13, n. 7, p. $8615-8627,2012$.

${ }^{4}$ CHEMAT, Farid et al. Green extraction of natural products. Origins, current status, and future challenges. TrAC Trends in Analytical Chemistry, v. 118, p. 248-263, 2019.

$5 \mathrm{XU}$, Li Da; XU, Eric L.; LI, Ling. Industry 4.0: state of the art and future trends. International Journal of Production Research, v. 56, n. 8, p. 2941-2962, 2018.

6 MASANGO, Phineas. Cleaner production of essential oils by steam distillation. Journal of Cleaner Production, v. 13, n. 8, p. 833-839, 2005.

${ }^{7}$ www.foodengineeringmag.com/articles

${ }^{8}$ www.smartindustry.com/articles/2016/the-evolution-of-manufacturing-executionsystems

${ }^{9} \mathrm{CHIARINI}$, Andrea; KUMAR, Maneesh. Lean Six Sigma and Industry 4.0 integration for Operational Excellence: evidence from Italian manufacturing companies. Production Planning \& Control, p. 1-18, 2020.

${ }^{10}$ MACHADO, Carlos Alberto Tosta; DE ANDRADE, Matheus Antonio Nogueira; LEPIKSON, Herman Augusto. Manufacturing 4.0: Discussion on Application in the Extractive Industry of Essential Oils. JOURNAL OF BIOENGINEERING AND TECHNOLOGY APPLIED TO HEALTH, v. 2, n. 3, p. 8691, 2019

${ }^{11}$ ANSI/ISA-5.1-2009 - Instrumentation Symbols and Identification [S.I.], 2009.

12 FILLY, Aurore et al. Water as a green solvent combined with different techniques for extraction of essential oil from lavender flowers. Comptes Rendus Chimie, v. 19, n. 6, p. 707-717, 2016.

${ }^{13}$ LITVINOVA, O. M.; LEVACHKOVA, Yu V.; CHUSHENKO, V. M. Determination of the critical parameters of the technological process control for pessaries with acyclovir and essential oils during industrial production. Social Pharmacy in Health Care, v. 3, n. 4, p. 59-64, 2017. 